\title{
Kompetencije knjižničara i informatologa: izazovi u vremenu društvenih i kulturnih promjena
}

\section{Competencies of librarians and informatologists: challenges in the time of social and cultural changes}

\section{Tatjana Aparac-Jelušić ${ }^{1}$}

SAŽETAK: U članku se raspravlja o kompetencijama knjižničara i informatologa, nesuglasju oko nazivlja te nastojanjima da se istražuju razni utjecaji na akademsko obrazovanje u polju informacijskih znanosti. Ukazuje se na promjene u europskom obrazovnom prostoru i izazove koji su potaknuli pokretanje i financiranje EINFOSE projekta. Posebna se pažnja usmjeruje prema kompetencijama knjižničara i informatologa iz motrišta EINFOSE projekta.

KLJUČNE RIJEČl: akademsko obrazovanje, knjižničari, informatolozi, kompetencije, EINFOSE projekt

ABSTRACT: In this paper we discuss the competencies of librarians and informatologists, terminological disagreements as well as attempts to investigate the various paths of influence on academic education in the field of Information sciences. We focus on changes in European educational arena and stimulus that encouraged the start-up and funding of EINFOSE project. Special attention is paid towards competencies of librarians and informatologists from the perspective of EINFOSE project.

KEYWORDS: academic education, librarians, informatologists, competencies, EINFOSE project

\section{Uvod}

Rasprave o kompetencijama knjižničara i informatologa postaju u posljednje vrijeme sve intenzivnije. Kao prvo, razvidno je nesuglasje kada je riječ o samim nazivima profesija (na primjer, knjižničar, informatolog, informacijski stručnjak), ali i kada je riječ o novim profilima koji se javljaju i za koje se traže odgovarajuće kompetencije i primjereno nazivlje. Opredijelili smo se za dva naziva informacijskih stručnjaka koje pratimo u ovome radu: knjižničare $\mathrm{i}$ informatologe. O knjižničarskoj profesiji i kompetencijama knjižničara napisano je mnogo radova tijekom 20. stoljeća. O informatolozima se, međutim, još uvijek govori sporadično, a kad ih se spominje, češće se koristi naziv informacijski stručnjak / znanstvenik prema engleskoj sintagmi information specialists / information scientists. Kako smatramo da je uporaba naziva za profesiju, sastavljenog od dviju riječi, nepodesna te da ta sintagma na engleskom jeziku ne odražava jasno o čemu se radi, priklonili smo se terminu 'informatolog', slijedom prakse izvođenja niza drugih naziva sa sufiksom - log (sociolog, pedagog, mikrobiolog, tehnolog i drugi). Polazeći od latinske osnove 'informare' i dodajući nastavak koji proizlazi iz grčke riječi 'lógos', složen je izraz informatolog, kako bi se uputilo na to da se radi o osobama koje se bave proučavanjem informacija i djelovanjem u širokom spektru informacijsko-komunikacijskog lanca. Informatolog još nije na ljestvici reguliranih profesija, ali se razumijeva da se njegove

Članak je nastao na osnovu istoimenog pozvanog izlaganja na konferenciji COBISS 2018, 28. 11. 2018.

Nekoliko dijelova članka oslanjaju se na poglavlje o preporukama iz dokumenta Policy Recommendations for Entry Requirements and Harmonization of Learning Outcomes, koji je izrađen u sklopu projekta EINFOSE.

1 Prof. dr. sc. Tatjana Aparac-Jelušić, u miru, Mrkopalj, Hrvatska, aparact@gmail.com. 
kompetencije temelje na bazičnim predmetnim kompetencijama knjižničara kojima su pridodana znanja i vještine uporabe i upravljanja informacijskom i komunikacijskom tehnologijom (IKT) i digitalnim izvorima. S takvim kompetencijama, informatolog je nezaobilazan suradnik u okruženju knjižničnih ustanova, ali i u računalnim i softverskim tvrtkama, vezano uz upravljanje bazama podataka, oblikovanje informacijskih usluga unutar mrežnog prostora, vrednovanje digitalnih informacija i slično. Zanimanje studenata za programe informatologije (na primjer, na Sveučilištu u Osijeku) i visok postotak njihove zapošljivosti u privatnim softverskim tvrtkama, pokazuju da je vrijedno i nužno potrebno pratiti i predviđati razvojne tijekove informacijskih djelatnosti te istraživati jezgrene sadržaje unutar široko postavljenog polja informacijskih znanosti, kako bi se argumentirale promjene novih znanstvenih paradigmi i opisali novi profili informacijskih stručnjaka.

Pitanja, vezana uz pristupe obrazovanju raznolikih profila informacijskih stručnjaka, dakako su vezana uz razumijevanje razvojnih pravaca informacijskih disciplina, uključujući mogućnosti konvergencije određenih sadržaja i stjecanje potrebnih vještina za rad i istraživanja u širokom polju informacijskih djelatnosti i znanosti. Brojne dvojbe oko nazivlja izravno su povezane uz identitet polja i njegovih grana (disciplina) te odnosa i preklapanja sa srodnim poljima, poput računalne znanosti odnosno djelatnosti, upravljanja informacijama, pedagogijom, filozofijom, lingvistikom, psihologijom. Pojedine grane, proizašle iz prepoznate nužnosti suradnje informacijskih znanosti i navedenih polja, na putu su ka osamostaljivanju - na primjer, digitalna humanistika, upravljanje informacijama, obrada jezika, informacijska etika. Kako je promjena znanstvenih paradigmi dug i iznimno zahtjevan proces, trenutno svjedočimo određenoj dozi nesigurnosti o mogućim pravcima razvoja informacijskih znanosti, što nesumnjivo utječe na mnoštvo raznovrsnih programa koji se nude unutar akademske zajednice širom svijeta.

U dokumentu Policy Recommendations (2018), koji je priređen u sklopu europskog projekta EINFOSE (European Information Science Education: Encouraging mobility and learning outcomes harmonization, http://einfose.ffos.hr), ističe se da je moguće povlačiti paralele između knjižnične i informacijske znanosti (KIZ) i informacijske znanosti (IZ), ali je uočljivo nesuglasje o tome kako opisati sličnosti i razlike i gdje povući granice. Cilj ovoga rada, međutim, nije utvrđivanje definicije jednog ili više polja i pripadajućih disciplina. Namjera nam je problematizirati najznačajnije pristupe $u$ akademskom obrazovanju, kako bismo ukazali na izazove i moguće odgovore s kojima se susreću visokoškolske ustanove na svim trima razinama: preddiplomskoj, diplomskoj i poslijediplomskoj.

Obrazovanje informatologa i drugih informacijskih stručnjaka, bez sumnje je duboko utemeljeno u programima za knjižničare, koji su se mijenjali, bogatili, ali nažalost i propuštali isticati temeljna znanja i vještine po kojima se knjižničari izdvajaju iz drugih profesija te ona obilježja po kojima su jedinstveni na ljestvici reguliranih profesija. Potrebno je odmah istaknuti da je u 1960.-im, na mnogim sveučilišnim odjelima ili samostalnim knjižničarskim školama, započeo proces spajanja s drugim odjelima koji su unutar akademske zajednice imali veći utjecaj (na primjer, računalstvo, menadžment) ili pak dulju tradiciju sveučilišnog obrazovanja (na primjer, pedagogija, književnost i jezici). Najčešće promjene naziva bile su one u kojima su takve nove jedinice nazivane knjižnična i informacijska znanost/studije. Oko 1990.-ih bilježi se sve češće ispuštanje riječi 'knjižnica' iz naziva tih obrazovnih jedinica te slijedom toga 
postupno prihvaćanje novih naziva, poput odjela za informacijsku znanost/studije, ili pak iškola.

U istraživanju koje je proveo A. Borrego (2015), ustanovljeno je da se najveći broj programa vezanih uz obrazovanje knjižničara nudi na odjelima za komunikacijske znanosti, knjižnične i informacijske znanosti, kao i humanistike, uglavnom kada je riječ o baštinskim i lingvističkim studijama.

S druge strane, Informacijske znanosti (u množini) prigrlile su discipline iz tzv. AKM sektora (arhivi, knjižnice, muzeji), dokumentalistiku, enciklopedistiku, leksikografiju, upravljanje bazama znanja i druge. U mnogoljudnim državama, programi unutar tako široko postavljenog polja ističu se raznolikošću profila na koje se fokusiraju i koje nude sveučilišni odjeli slijedom potreba informacijskih ustanova za specijalistima različitih profila. U zemljama malih jezičnih zajednica i sa skromnim brojem informacijskih ustanova (ako se izuzmu narodne, školske i visokoškolske knjižnice, a donekle i muzeji), teško je postići raznolikost programa, jer su ovisni o raspoloživom znanstveno-nastavnom osoblju i njihovim specijalizacijama s jedne strane te manjim brojem studenata koji se odlučuju na studije informacijskih znanosti slijedom saznanja o raspoloživim radnim mjestima.

U ovome radu oslanjamo se na stajalište Bawdena i Robinsonove (2013) prema kojemu se informacijske znanosti preklapaju s brojnim disciplinama u fokusu kojih je proučavanje informacijsko-komunikacijskog procesa iz motrišta proizvodnje, organizacije, pohrane, čuvanja i korištenja informacija. Navedeni autori koriste sintagmu 'cjelovit komunikacijski lanac', a zanimaju ih načini interakcije svih sudionika koji sudjeluju u tom lancu, što nesumnjivo predstavlja izazov za obrazovanje tih sudionika te njihovo usmjeravanje prema specifičnim profilima.

Pritom, valja zagovarati pristup koji polazi od temeljnih kompetencija za široko polje informacijskih znanosti i zajedničke teorijsko-metodološke jezgre. Naša će pažnja biti usmjerena poglavito na kompetencije knjižničara i informatologa, jer zagovaramo pristup prema kojemu se uz knjižničare postupno udomaćuje profesija informatologa. Smatramo da je izraz informatolog primjereniji, da omogućava jasno iskazivanje profesionalnog identiteta, korištenje pridjevskih konstrukcija (svakako spretnije no što je slučaj pri uporabi termina informacijski stručnjak).

\section{Europski obrazovni prostor u polju knjižnične i informacijske znanosti}

U stručnoj se literaturi ukazuje na to da je od konca 80.-ih godina 20. stoljeća europsko akademsko obrazovanje prolazilo kroz faze znakovitih promjena kojima se nastojalo odgovoriti na promjene iz okruženja, prevladati tromost sveučilišnih struktura i mehanizama, ali i sačuvati pozitivna iskustva utemeljena na višestoljetnoj akademskoj tradiciji. Nakon početnih aktivnosti Bolonjskog procesa, prva su dva desetljeća 21. stoljeća obilježena uspostavljanjem i djelovanjem EHAE (European Higher Education Area), unutar koje se potiče fleksibilnost i suradnja na oblikovanju i ponudi akademskih obrazovnih programa.

U tim procesima informacijske su se tehnologije pokazale izvrsnim osloncem za nove pristupe u akademskom obrazovanju i nove načine komuniciranja među dionicima obrazovnih procesa. Međutim, za njihovu primjenu u nastavi, uz osiguranje odgovarajuće informacijskokomunikacijske infrastrukture, bilo je nužno učiniti iskorake u pripremi nastavnog i tehničkog 
osoblja, osobito u odnosu na prihvaćanje suradnje i partnerskih odnosa kao conditio sine qua non unapređenja obrazovnog procesa te se snažnije osloniti na druge stručnjake, među kojima su knjižničari, a sve više i informatolozi, prepoznati kao iznimno vrijedni i odgovorni suradnici.

Velike promjene u akademskome obrazovanju događaju se i u drugim sredinama, kako onima u razvoju, tako i u zemljama koje su tijekom 20. stoljeća prednjačile u iskoracima prema modernijim obrazovnim okvirima (na primjer, Finska, SAD, Kanada, Australija). Novi pristupi nesumnjivo su imali dugotrajan utjecaj na pomake s koncepta poučavanja prema konceptu samostalnog učenja, odnosno podučavanja u kojemu je student središnja točka svih nastojanja (više o tome u Petr i Aparac-Jelušić, 2002). Drugi važan iskorak odnosi se na praćenje i vrednovanje učinaka (outcomes) što ih sveučilišta imaju na svoje studente, pa je u tom pravcu provedeno niz istraživanja (uglavnom u SAD-u, Kanadi i Australiji, a tek u začecima unutar europskog visokoškolskog obrazovanja), kojima se nastojalo dokazati kakav je utjecaj knjižnica na uspjeh studenata i njihovo snalaženje u radnim sredinama (usp. na primjer, Zuñiga-Ruiz et al., 2009; Arko-Cobbah, 2013; Goebel, 2013; Beilin, 2016; Murray i Aschley, 2017; Connaway et al., 2017). Posebno je vidljiv utjecaj knjižnica na pet područja: dobrobiti za početne zadatke studenata u nastavi, jačanje njihova uspjeha tijekom studija, podršku kvalitetnoj suradnji studenata pri izvedbi suradničkih projekata, osnaživanju informacijske pismenosti kojom se pojačava opći uspjeh na studiju te podršku knjižničnog osoblja koje savjetuje i vodi studente u njihovim istraživačkim naporima (usp. Association, 2017).

Pomaci prema novim konceptima učenja i podučavanja, koji od konca 1990.-ih sve više zastupaju i sami sveučilišni nastavnici, pred knjižnice su počeli postavljati velike zahtjeve, koji često nisu bili praćeni odgovarajućom financijskom i kadrovskom podrškom. Međutim, promijenjene okolnosti utjecale su na to da su knjižničari prepoznali priliku za promjenom svog položaja unutar visokoškolskih i znanstvenih ustanova te su postupno preuzimali nove zadaće (na primjer, podrška e-učenju, informacijsko opismenjavanje, upravljanje e-izvorima) i nudili nove usluge (na primjer, bibliometrijske analize, e-posudbu, iznajmljivanje opreme), koje su sposobni obavljati za potrebe promijenjenih nastavnih programa i metoda podučavanja. Uz njih i knjižničari u školskim i narodnim knjižnicama bogate svoje usluge u području informacijskog opismenjavanja, programa društvene inkluzije i slično.

Dakako, europski obrazovni prostor obilježen je raznim tradicijama i veoma se razlikuje od zemlje do zemlje te zahtijeva pažljivo odabrane pristupe koji će omogućiti postupne prilagodbe i upravljanje kompleksnim analognim i digitalnim informacijskim sustavima u obrazovnim procesima. U takvom okruženju postajalo je razvidno da se u akademsko obrazovanje knjižničara trebaju unositi novi sadržaji i koristiti nove didaktičke metode, nadograđujući ih na prihvaćene temelje i dokazane vrijednosti profesije te nastojeći približiti ishode učenja, kako bi se olakšala mobilnost i priznavanje diploma.

Međutim, unatoč višestrukim naporima u pravcu harmonizacije programa u polju knjižnične i informacijske znanosti, danas je više nego razvidno da se obrazovni programi razlikuju po svojim sadržajima i strukturi te da nastojanja zagovornika Bolonjskog procesa nisu polučila ujednačenost čak ni na razini strukture studija. Primjer za to je nastojanje da se prihvati model $3+2+3$ koji ipak nije zaživio u svim sredinama, pa se susreću studijski programi $4+3,5+3$, i slične kombinacije. 
Kritičari ideje Bolonjskog pristupa upozoravali su od samih početaka na to da su određena akademska polja - za nas, u ovome radu, od posebnog interesa šire polje informacijskih znanosti - raznovrsno postavljena i iznimno kompleksna, jer se radi o mladim akademskim disciplinama koje od 1950.-ih tragaju za svojim teorijsko-metodološkim uporištima, zasnivaju vlastite programe na različitim tradicijama, pristupima i modelima, što je vodilo prema ponudi takvih programa koji se mogu relativno jednostavno nastaviti na postojeće modele. Dobri primjeri za navedenu tvrdnju bili su, a u nekim sredinama i dalje jesu, povezanost knjižnične znanosti s književnošću i jezicima ili pedagogijom, arhivistike $s$ poviješću, računalstva $s$ elektrotehnikom, i slično. Moguće je ustvrditi da su te različitosti proizašle iz povijesnih, kulturoloških, društvenih, ekonomskih i političkih situacija (na primjer, utjecaj austrougarskog knjižničarstva do duboko u 20. stoljeću na zemlje koje su bile pod upravom Austro-ugarske monarhije, utjecaj sovjetskog knjižničarstva na zemlje članice tzv. istočnog bloka i njihovu duboku uronjenost u bibliologiju i teoriju čitanja, utjecaj dokumentalistike na francusko i španjolsko knjižničarstvo, odnos prema javnom knjižničarstvu i prepoznavanju njegove važnosti za razvoj društva u skandinavskim zemljama). To je nesumnjivo u nekim situacijama otežavalo procese prilagodbe ciljevima Bolonjske deklaracije, a u drugima ih se naprosto prihvaćalo deklarativno, dopuštajući vlastitim modelima da se postupno mijenjaju slijedom utvrđenih lokalnih potreba.

Postavlja se pitanje da li ta raznolikost donosi novu snagu kojom Europa korača kroz 21. stoljeće ili je posljedica slabosti da se prepoznaju izazovi oblikovanja programa za nove, danas i u skoroj budućnosti tražene profile knjižničara i informatologa. Pojedini autori zastupaju stajalište prema kojemu je pluralizam temelj snage za budući znanstveni, obrazovni i profesionalni razvoj unutar široko postavljenog polja informacijskih znanosti (usp. na primjer, Audunson 2005, Audunson i Suva, 2016; Tammaro 2007), drugi su pak zabrinuti da raznolikost ugrožava transparentnost i mobilnost studenata i nastavnika, a time predstavlja značajne probleme u postavljanju združenih programa te za suradnju među europskim visokoškolskim ustanovama općenito (usp. Aparac-Jelušić, 2007; Virkus, 2008; Johnson, 2013; Golub, Hansson i Selden, 2017). Prema Kajbergu (2007, str. 69) raznolikost definitivno ima određenu dozu šarma, ali je usto i vrijedna imovina s kojom treba ozbiljno računati.

Raspravljajući o temeljnim znanjima i sadržajima u polju informacijskih znanosti na europskoj razini, uz neizbježnu raspravu o identitetu samog polja, nužno je potrebno problematizirati nove profile u društvenim znanostima, humanistici i STEM području te se fokusirati na ona znanja i vještine kojima se informacijske znanosti izdvajaju od drugih akademskih i znanstvenih polja i disciplina. Da bi se to postiglo, valja se fokusirati na temelje polja i načine uključivanja drugih sadržaja (iz pedagogije, psihologije, kulturalnih studija, komunikologije, računalne znanosti, biologije i drugih), u cilju oblikovanja novih profila knjižničara i informatologa, arhivista i drugih. Pritom se nastoje postaviti i protumačiti okviri (frameworks) unutar kojih su postavljene liste željenih ishoda učenja te usuglašeni profili na nacionalnim i međunacionalnim razinama između svih zainteresiranih dionika (obrazovnih ustanova, poslodavaca, stručnih udruga, nadležnih ministarstava i drugih), a prije svega vezano uz:

- obrazovne potrebe i dogovore oko kvalitativnih vidova ponuđenih/željenih profila, ciklusa i razina;

- predmetne benchmarking analize poradi jačanja kvalitete pojedinih programa;

- suradnju koja zagovara snažnije uporište u kritičkoj pedagogiji; 
- nastavne materijale, načine ocjenjivanja, vježbe i praktičan rad;

- mogućnost ugrađivanja mobilnosti kao važnog oslonca kvalitete, što povlači jasne odluke vezano uz priznavanje ECTS-a, odnosno kojeg drugog relevantnog pokazatelja ishoda učenja.

\section{Kompetentni knjižničari i informatolozi - pogled iz motrišta EINFOSE projekta}

U situaciji koju obilježuju različite tradicije i pristupi, sveučilišni nastavnici okupljeni oko Euclida (European Association for Library and Information Education and Research) 20032005., a posljednje dvije godine i projekta EINFOSE (financiranog u sklopu Erasmus + programa), pokušavali su iznaći optimalna rješenja koja bi vodila prema usklađivanju obrazovnih jezgri, ishoda učenja i jedinstvenih kriterija za upis na diplomske studije iz informacijskih znanosti. EINFOSE projekt postavio je svoje ciljeve na tragu EU programa Europe 2020 (European Commission, 2010), osobito njegovih ključnih prioriteta:

- Plana za modernizaciju (Modernization agenda) koji se usmjerava prema unapređenju kvalitete i relevantnosti digitalnog podučavanja i učenja, jačanju i promicanju ideje mobilnosti nastavnika i studenata kroz EU obrazovni prostor i međudržavnu suradnju te stavlja naglasak na važnost 'trokuta znanja' (knowledge triangle) unutar kojega se povezuju obrazovanje, znanost i inovacije;

- Plana transparentnosti i priznavanja vještina i kvalifikacija u cilju olakšavanja učenja, zapošljivosti $i$ mobilnosti na radu (Transparency and recognition of skills and qualifications to facilitate learning, employability and labor mobility).

Polazeći od tih, unaprijed zadanih ključnih prioriteta, EINFOSE projekt svojim je intelektualnim rezultatima težio pridonijeti jednostavnijem priznavanju digitalnih vještina i kvalifikacija među partnerskim visokoškolskim ustanovama te modernizaciji obrazovanja u polju informacijskih znanosti. Naime, EINFOSE projekt pokrenut je s idejom da partneri (osam europskih sveučilišta) obogate vlastiti obrazovni prostor i razvojne planove učeći jedni od drugih, oslanjajući se na prepoznate snage (ekspertizu i iskustvo) svake pojedine partnerske ustanove te uočene slabosti (nemogućnost ponude specifičnih a traženih profila, na primjer uslijed malog broja nastavnika i nedostatka suradnje). Istraživanja provedena unutar projekta bila su usmjerena prema problemu upravljanja promjenama u visokom obrazovanju u polju informacijskih znanosti, novim didaktičkim pristupima, jačanju online dostupnih nastavnih materijala i komunikacijske platforme te vrednovanju raznih vidova pripreme i izvedbe online nastave.

U svjetlu promjena koje se događaju poseban je naglasak stavljen na nove izazove $u$ obrazovanju, prepreke s kojima se partnerske ustanove susreću te usuglašavanje oko znanja i vještina u polju informacijskih znanosti u 21. stoljeću. U literaturi je uočljiv niz rasprava o tzv. kompetencijama za 21. stoljeće, predstavljeni su didaktički okviri i slično, da bi se prepoznali određeni konvergencijski pristupi poput, modela 4Cs koji se fokusira na tzv. supervještine kreativnost, komunikabilnost, kritičko mišljenje i sposobnosti suradničkog djelovanja (usp. Marić, 2017), ili pak modela koji je sintetizirao petnaestak različitih obrazovnih okvira objedinjenih unutar sljedećih razina: 
- temeljna znanja (temeljna opća znanja, digitalna i računalna pismenost, međudisciplinarna znanja);

- humanistička znanja (vještine potrebne za život i rad, svijest o etičkim i emotivnim vrednotama, kulturalne kompetencije);

- metaznanja (komunikacija i suradnja, rješavanje problema i kritičko mišljenje, kreativnost i inovativnost) (usp. Kereliuk et al., 2013).

Međutim, unatoč tomu što su uložena značajna sredstva u istraživanja i razvoj, poglavito vezano uz uvođenje novih kompetencija, reviziju postojećih programa, odabir, primjenu i praćenje novih pristupa, koji bi motivirali i uključivali studente u nastavu (poput 'obrnute' učionice - flipped classroom, online edukacijskih izvora - OER-a i masivnih online predmeta MOOCs, učenja kroz podučavanje - learning by teaching), stvaranje novih obrazovnih prostora (na primjer, interaktivnih laboratorija za podučavanje i učenje) i dodatno obrazovanje nastavnika, akademska je izobrazba u polju informacijskih znanosti i nadalje neistraženo područje kojemu nedostaju egzaktni pokazatelji o prihvaćenosti, zadovoljstvu ili problemima vezanim uz pojedine pristupe i modele.

Globalizacija visokoškolskog obrazovnog prostora nesumnjivo je utjecala na sadržaj kurikuluma, načine podučavanja, učenja, kompetencije nastavnog osoblja i kvalitetu programa. Predmeti koji se bave novim vidovima informacija (na primjer, vlasničkim pravima nad informacijama, računalnom etikom, osiguranjem i zaštitom informacija, digitalnom podijeljenošću, digitalnom baštinom, skrbi nad digitalnim informacijama, grafičkim oblikovanjem i vizualizacijom), privlače studente, bez obzira na to za koji su se studijski program unutar polja opredijelili (na primjer, knjižničarstvo, informatologiju, arhivistiku, ili digitalnu humanistiku).

U sklopu EINFOSE projekta ponuđena su razmišljanja, zaključci i preporuke kojima se nastoji ukazati na to što pojedina kompetencija znači za studente informacijskih znanosti, na koji način mogu ovladati određenim znanjima i vještinama, kroz koje sve aktivnosti i na koji način studenti mogu sami procjenjivati stupanj vlastitih postignuća. Također, nastojalo se izdvojiti kompetencije kojima se teži na općoj razini učenja, podučavanja i djelovanja (kreativno i prilagodljivo mišljenje, suradničko rješavanje problema, suosjećanje i međusobno poštovanje, posvećenost učenju i upravljanju znanjem), opće i specifične vrijednosti koje su integralna sastavnica svakog profesionalnog identiteta (izvrsnost, kreativnost, intelektualna znatiželja, strast za učenjem) te one vrijednosti koje su imanentne profesiji knjižničara kao temelj na kojem se dalje grade specifični profili (organizacija informacija, opći pristup zabilježenom znanju i informacijama, suradnja, intelektualna sloboda, samousmjeravajuće učenje, vođenje (usp., na primjer, zapažanja Marchioninija i Moranove, 2012; Machale, 2015).

Polazna točka u nastojanjima da se prikupe, analiziraju i pretoče u preporuke zajednički stavovi partnerskih ustanova bio je skup kompetencija za knjižničare i informatologe na osnovi kojih bi se mogla postizati željena razina harmonizacije ishoda učenja i poticati internacionalizacija u europskom obrazovnom prostoru. Ti su se stavovi oslanjali na dokumente profesionalnih društava unutar polja knjižničarstva i informatologije: ASIST (American Association for Information Science and Technology), LIANZA (Library and Information Association of New Zealand Aotearoa), ALA (American Library Association), ALISE (Association for Library and Information Science Education), CILIP (Chartered Institute of Library and Information 
Professionals), ALIA (Australian Library and Information Association), SLA (Special Libraries Association) i drugih. (usp. Policy Recommendations, 2018)

Uz navedene dokumente, proučene su i specifične kompetencije kako ih vide pojedine subdiscipline poput onih koje se, na primjer, bave upravljanjem podacima COAR (Confederation of Open Access Repositories), upravljanjem informacijama, dokumentima i zapisima (Government of Newfoundland and Labrador i Records and Information Management Core Competencies), ACRL Competencies for special collections professionals i drugi. U obzir su uzeti kvalifikacijski okviri koji su usvojeni (ili se pripremaju) na nacionalnim i međunarodnim razinama, kao što su: ISCO (International Standard Classification of Occupations), NACE (Statistical Classification of Economic Activities in the European Community), EQF (European Qualifications Framework), DigComp (European Digital Competence Framework for Citizens) i slični.

Naposljetku, analiziran je dokument IFLA BSLISE Working Group (2018) u kojemu su predstavljeni ključni nalazi provedene analize za potrebe IFLA-e (International Federation of Library Associations and Institutions) (usp. Policy Recommendations, 2018).

Prema tom istraživanju, trenutna situacija pokazuje:

- da se potiču i podržavaju preddiplomski i diplomski studiji iz knjižničarstva i informatologije u mnogim zemljama, ali da titule koje se stječu nakon provedene izobrazbe nisu usklađene te da ne postoje međunarodni standardi koji bi omogućavali usporedbu, prepoznatljivost odnosno priznavanje stečenih kompetencija;

- da se u mnogim zemljama, koje su sudjelovale u istraživanju, zahtijevaju potvrde o stečenom obrazovnom stupnju, međutim, rijetko se susreće da su lokalno prihvaćene diplome/potvrde priznate izvan okvira određene sredine, čime se slabi vjerodostojnost napora za prepoznavanjem standarda osiguranja kvalitete (Quality Assurance - QA);

- da mnoge zemlje imaju formalne lokalne strukture, odnosno prihvaćene pristupe osiguranju kvalitete (na primjer, akreditacijska tijela, profesionalne udruge, profesionalne povelje) ili posebne regulatorne mehanizme, ali da ima zemalja kojima takvi pristupi i mehanizmi nedostaju, iako o njima raspravljaju.

- da postoje raznolike kvalifikacijske strukture koje su prihvaćene unutar pojedine sredine, ali da ih druge sredine ne razumiju ili su nedovoljno s njima upoznate (usp. IFLA BSLISE Working Group, 2018).

Dodatno, u mnogim sredinama se ne zahtijevaju diplome/potvrde unutar šireg polja informacijskih znanosti (na primjer, za muzeologe, arhiviste), a u posljednje vrijeme bilježi se i otvaranje prostora za rad u knjižnicama bez temeljnih kvalifikacija, čak i u zemljama koje imaju dugu i respektabilnu tradiciju obrazovanja knjižničara, na primjer, Poljska (Antczak i Gruszka, 2018).

Ključne preporuke iz dokumenta, koji je priredila IFLA-ina radna skupina (IFLA BSLISE Working Group, 2018), jesu:

- da je potrebno identificirati ključne i druge kompetencije u cilju jačanja transferabilnosti i reciprociteta;

- da je potrebno razviti međunarodni okvir za procjenu standarda kvalitete u području obrazovanja za knjižničare i informatologe; 
- da je potrebno izgraditi lokalnu infrastrukturu, tamo gdje nedostaje, temeljeći ju na prednostima lokalne zajednice i tradicije;

- da je korisno razviti međunarodnu bazu podataka kojom se identificiraju lokalne strukture;

- da se razvije „sistem“ kvalifikacija/akreditacija, uključujući discipline u širem polju informacijskih znanosti;

- da se definira i razumije što je ustvari polje knjižnične i informacijske znanosti i koje implikacije iz toga proizlaze za obrazovanje knjižničara i informatologa i njihov profesionalni razvoj. (usp. Južnič, Renon i Heco, 2018).

Dokument, koji je priredio EINFOSE tim, osim što donosi opsežan uvid u obrazovanje informacijskih stručnjaka, dodatno sugerira i dva druga pristupa, vezano uz usuglašavanje ishoda učenja, kako bi se naglasile temeljne kompetencije:

- da treba poticati i promicati svijest o važnosti identifikacije polja informacijskih znanosti uz naglašavanje specifičnosti i zajedničkih teorijsko-metodoloških osnova. Time bi se ujedno mogao dokumentirati nukleus užeg polja informacijske znanosti (Informatologije?), izdvojiti differencia specifica u odnosu na druge discipline unutar šireg polja informacijskih znanosti, što bi vodilo prema usuglašavanju oko sadržaja, znanja i vještina kojima studenti trebaju ovladati da bi postali informacijski profesionalci;

- da treba nastaviti s naporima oko ponude programa za specijalizaciju, uz jasno izdvajanje profesionalnih i akademskih kompetencija, čime se može odgovoriti na potrebe radnih mjesta te olakšati razmjena studenata i nastavnika, kao i njihovo umrežavanje.

\section{Zaključak}

Polje knjižnične i informacijske znanosti prošlo je kroz razdoblje u kojemu se govorilo o dvjema odvojenim i različitim disciplinama. Samo knjižničarstvo, prihvaćajući izazove okruženja za koje se postavljaju nove službe i nude raznolike usluge, nametnulo se kao disciplina koja je širila svoje granice, s obzirom na vlastitu teoriju i praksu, a time je imalo izravan utjecaj na obrazovni sustav, uvodeći pritom stajališta o potrebi za novim vještinama i znanjima koja se nadograđuju na postojeća znanja i ne vezuju se nužno samo na knjižničnu ustanovu. Profesija informatologa još se dokazuje, iznalazi odgovarajuće nazivlje i izdvaja specifičnosti po kojima se informatolog razlikuje od knjižničara ili računalnog stručnjaka, a koje donose dodatne vrijednosti u polju informacijskih znanosti.

Prihvatimo li stajalište o nužnosti zasnivanja poslanja knjižničara i informatologa na potrebi da se društvu predstave svi zapisi koje je čovjek tijekom razvoja civilizacije stvarao, prikupljao i čuvao, a danas ih nevjerojatnom brzinom podastire i njima upravlja u digitalnom okruženju te da im je glavna zadaća osiguranje pristupa znanju i informacijama, korisno je prisjetiti se rasprava o kompetencijama knjižničara (usp. na primjer Wilson, 1983), kada je u središtu pozornosti bilo pitanje da li je knjižničar katalogizator, bibliograf, priređivač kazala, on line tragač, osoba koja odgovara na pitanja, osoba koja priča djeci priče, koja planira, ili rukovodi? Da li je knjižničar osoba koja objedinjuje u sebi gomilu vještina ili je pak nešto drugo? Danas se $u$ središte zanimanja postavljaju nove kompetencije koje bi mudro trebalo zasnivati na jedinstvenoj osnovi (temeljna znanja i vještine) i nizu specifičnih profila stručnjaka koji postavljaju, organiziraju, razvijaju i održavaju djelatnost u knjižnici i u mrežnom prostoru, 
polazeći od potreba pojedinaca i društva za vjerodostojnim informacijama i usvajanjem humanističkih vrijednosti.

O stupnju općih i stručnih znanja i vještina uvelike ovisi kvaliteta procesa u knjižničnom informacijskom sustavu i njegovu odnosu s okruženjem, ali i budućnost stručnjaka koji moraju odgovoriti na mnogobrojne izazove, intelektualne i tehničke prirode, nastale kao posljedica pojačanih promjena u društvu.

Rasprave o kompetencijama knjižničara i informatologa vezane su nesumnjivo uz identitete i poslanje tih profesija, uz svrhu djelovanja u današnjem društvu te uz prepoznavanje onih obilježja koja su pripisivana knjižničarima jučer, kako bi ih se koristilo danas i razvijalo u skladu s budućim potrebama za kompetentnim informacijskim profesionalcima.

\section{Reference}

Antczak, M. i Gruszka, Z., 2018. How to make new in the age of competition? Creating new education offer in the field of information science in Poland on the example of the University of Lødz. U: T. Aparac-Jelušić, V. Casarosa i E. Macevičiūtè, ur. The future of education in information science: proceedings from FEIS. T. Osijek: Faculty of Philosophy. Str. 199-205. Dostupno na: http://einfose.ffos.hr/feis-2018/proceedings [12. 5. 2019].

Aparac-Jelušić, T., 2007. Interdisciplinarni diplomski studij u polju informacijskih znanosti digitalizacija pisane baštine. U: P. Lučin i M. Kovačević, ur. Združeni studiji. Rijeka: Nacionalna zaklada za znanost. Str. 19-32.

Arko-Cobbah, A., 2013. The role of libraries in student-centred learning: the case of students from the disadvantaged communities in South Africa. International Information \& Library Review, 36(3), str. 263-271.

Audunson, R., 2005. Editorial: LIS and the creation of a European educational space. Journal of Librarianship and Information Science, 37, str. 171-174.

Audunson, R. A. i Shuva, N. Z., 2016. Digital library education in Europe: a survey. Sage Open, January-March, str. 1-17. Dostupno na:

https://journals.sagepub.com/doi/abs/10.1177/2158244015622538 [12. 5. 2018].

Beilin, I., 2016. Student success and the neoliberal academic library. Canadian Journal of Academic Librarianship, 1(1), str. 10-23.

Borrego, A., 2015. Library and information education in Europe: an overview. BiD, 35. Dostupno na: https://dx.doi.org/10.1344/BID2015.35.8 [10. 10. 2017].

Bowden, D. i Robinson, L., 2013. Introduction to information science. Chicago: NealSchuman.

Connaway, L. S., Harvey, W., Kitzie, V. i Mikitish, S., 2017. Academic library impact: improving practice and essential areas to research. Chicago: Association of college and research libraries. Dostupno na:

http://www.ala.org/acrl/sites/ala.org.acrl/files/content/publications/whitepapers/academicl ib.pdf [12. 5. 2018]. 
European Commission, 2010. EUROPE 2020 - a strategy for smart, sustainable and inclusive growth. Brussels, 3 March. Dostupno na:

http://ec.europa.eu/eu2020/pdf/COMPLET\%20EN\%20BARROSO\%20\%20\%20007\%20\%20Europe\%202020\%20-\%20EN\%20version.pdf [12. 5. 2018].

Goebel, M., 2013. E-learning in the European higher education area. Dostupno na: https://enqa.eu/wp-content/uploads/2015/12/E-learning-in-the-European-HigherEducation-Area Gaebel.pdf [12. 5. 2018].

Golub, K., J. Hansson i Selden, L., 2017. Cult of the "I": organizational symbolism and curricula in three Scandinavian iSchools with comparisons to three American. Journal of Documentation, 73(1), str. 48-74. Dostupno na: https://doi.org/10.1108/JD-04-2016-0042 [12. 5. 2018].

IFLA BSLISE Working Group, 2018. Building strong LIS education: a call to global and local action - an IFLA BSLISE Working Group White Paper. Cape Town: University of Cape Town Libraries.

Johnson, I., 2013. The impact on education for librarianship and information studies of the Bologna process and related European Commission programmes - and some outstanding issues in Europe and beyond. Education for Information, 30, str. 63-92.

Južnič, P., Renon, F. i Heco, T., 2018. Towards building strong LIS education: preliminary findings from an international environmental scan of LIS education, certification and professional identity (European focus). U: T. Aparac-Jelušić, V. Casarosa i E. Macevičiūtè, ur. The future of education in information science: proceedings from FEIS. Osijek: Faculty of Philosophy. Str. 112-122.

Kajberg, L., 2007. The European LIS curriculum project: an overview. Journal of Education for Library and Information Science, 48(2), str. 68-81.

Kereluik, K., Mishra, P., Fahnoe, C. i Terry, L., 2013. What knowledge is of most worth, Journal of Digital Learning in Teacher Education, 29(4), str. 127-140.

Marchionini, G. i Moran, B. ur., 2012. Information professionals 2050: educational possibilities and pathways. North Carolina: School of Information and Library Science of University of North Carolina at Chapel Hill. Dostupno na:

http://sils.unc.edu/sites/default/files/news/Information-Professionals-2050.pdf [12. 5. 2018].

Marić, J., 2017. EINFOSE Workshop, November 20, 2017, Boros, Sweden. Dostupno na: https://drive.google.com/open?id=OB ICli5ak57WblZqcXk1ZEdoTWs [10. 12. 2017].

Murray, A. L. i Aschley P. I., 2017. Communicating library impact on retention: a framework for developing reciprocal value propositions. Journal of Library Administration, 57(3), str. 311-326.

Petr, K. i Aparac-Jelušić, T., 2002. Uloga sveučilišnih knjižnica u novim pristupima akademskom obrazovanju. U: S. Tkalac i J. Lasić-Lazić, ur. Zbornik radova „Težakovi dani“. 
Zagreb : Filozofski fakultet, Zavod za informacijske studije Odsjeka za informacijske znanosti. Str. 159-171.

Policy recommendations, 2018. EINFOSE Policy recommendations on entry requirements and harmonization of learning outcomes. Dostupno na: http://einfose.ffos.hr/documents [12. 9. 2018].

Tammaro, A. M., 2007. A curriculum for digital librarians: a reflection on the European debate. New Library World, 108, str. 229-246.

Vilar, P. i Žumer, M., 2018. Unified entry requirements for information science programmes? Do we know who we want to attract? U: T. Aparac-Jelušić, V. Casarosa i E. Macevičiūtè, ur. The future of education in information science: proceedings from FEIS. Osijek: Faculty of Philosophy. Str. 179-186.

Virkus, S., 2008. LIS education in Europe: challenges and opportunities. U: V. Neugebauer, ur. Informationskonzepte für die Zukunft: ODOK'07, str. 191-204. Dostupno na:

http://eprints.rclis.org/14978/1/odok07 virkus.pdf [10. 8. 2017].

Wilson, P., 1983. Bibliographical R\&D. U: F. Machlup, i U. Mansfield, ur. Study of information: interdisciplinary messages. New York: Wiley. Str. 389-97.

Zuñiga-Ruiz, A., Needham, G., Virkus, S. i Harbo, K., 2009. E-MOVE project-a case of successful cooperation of European academic libraries of distance teaching universities. Dostupno na: https://www.researchgate.net/publication/43668244 E-MOVE projecta case of successful cooperation of European academic libraries of distance teaching universities [12. 5. 2018]. 